\title{
The Management of 'Tahfidz Al-Qur'an Learning at Homeschooling Public Learning Center
}

\author{
Raudhah Saragih $^{1)}$, Mesiono $^{2)}$. Inom Nasution ${ }^{3)}$ \\ 1,2,3 Universitas Islam Negeri Sumatera Utara Medan, Indonesia \\ raudhahsaragih@gmail.com, mesiono@uinsu.ac.id, inomnasution@uinsu.ac.id
}

Received: 12-08-2021

Revised: 26-10-2021

Accepted: 10-11-2021

\section{Abstract}

Keywords:

Learning Management, Tahfizh Al-Qur'an, Homeschooling.
This article aims to determine and analyze the Tahfidz Al-Qur'an Learning Management at Homeschooling Public Learning Center of Abi And Ummi Junior High School Level of Islamic Education Foundation Jannati Medan Helvetia, which includes planning, organizing, implementing, and evaluating. Researchers are interested in knowing more about the management of tahfidz Al-Qur'an learning in this school because in its application this school is homeschool-based with the target of tahsin reading the Qur'an in conjunction and using STIFIn as a learning aid. This article uses a case study approach and uses three sources of evidence to be the focus of data collection in this study, namely: direct observation, interviews, and documentation. Data analysis in this study is in the form of making a detailed description of the case. In data analysis, the researcher reduces the data by summarizing, choosing the main things, focusing on the important things, looking for themes and patterns, and removing unnecessary ones, so that the reduced data provides a clearer picture. Then the researcher displays the data (presents the data) to make it easier to understand what is happening. Furthermore, the researcher carried out a conclusion drawing (concluding drawing/verification). The result of this article indicates that the planning of tabfidz. Al-Qur'an learning is in the form of recruitment of supervising teachers, standards in new student admissions, preparation of learning programs, and setting memorization targets as a form of optimizing the homeschooling base where schools are expected to be able to create a comfortable and enjoyable learning and tabfidz atmosphere. so that it can give birth to Hafizh Al-Qur'an with the quality of reading Quran well. Organizing tahfidz Al-Qur'an learning using STIFIn as a tool to identify student intelligence machines to direct students to recognize appropriate memorization methods and teachers can take a personal approach to students so that students feel comfortable while memorizing the Qur'an and grow a love of Al-Qur'an -Qur'an. The implementation of tahfidz AlQur'an learning is in the form of face-to-face small groups where one supervising teacher is responsible for 8-10 students. The schedule for implementing the tahfidz Al-Qur'an learning is prepared by the tahfidz coaches, school principals and supervising teachers. There are 6 hours in a daily special time provided for tahfizh learning which is divided into 3 meetings, the first 1 hour to increase memorization, the second 3 hours to repeat memorization and the third 2 hours to increase memorization. Evaluation of tahfidz Al-Qur'an learning that is applied in the form of evaluations per day, month, and semester. 


\section{INTRODUCTION}

One of the efforts to improve the quality of education is done through improving the quality of learning. Improving the quality of learning requires good learning management. Learning management in the functional tasks of teachers will be effective and efficient if the teacher is able to act as a manager in creating a learning atmosphere through the use of teaching and learning facilities. As according to Buchari (2018:106) the results of the theoretical study show that learning management in the functional tasks of teachers will be carried out effectively and efficiently if the teacher is able to carry out his role as manager of instruction in creating learning situations through the use of teaching and learning facilities.

A professional teacher by itself will wake up over time. Developing professional duties as educators and teachers makes teachers have a lot of experience in accordance with the development of science and technology. Quality teachers pay attention globally in order to improve learning and advance education (Buchberger et al. 2000). Being an educator (teacher) involves more than just a position (A. Goodwin \& Kosnik, 2013:334). This is because teachers are the school's greatest asset. The position of the teacher as a learning manager makes the teacher at the forefront of realizing educational goals.

In learning management the teacher's role as a manager has a significant influence on the effectiveness of the learning process. In accordance with the opinion of Gemnafle \& Batlolona (2021:33) the role of the teacher in the process of implementing learning in schools cannot be replaced by other learning sources in the form of technology. Erwinsyah (2017: 70) also states that the teacher's responsibility is not only limited to the process of transferring knowledge. One thing that teachers need to pay attention to is their expertise in managing learning.

Various activities carried out by teachers in relation to learning management include planning learning materials, formulating learning objectives, organizing and developing learning materials, establishing harmonious communication with school principals, controlling classes, presenting teaching materials, building and maintaining relationships and constructive educative communication. with students, motivate and build students' enthusiasm for learning, evaluate and follow up on student learning outcomes (Gemnafle \& Batlolona, 2021:37). The success of students in learning is largely determined by the learning strategies carried out by the teacher. Teachers are required to understand the basic components in classroom learning activities. Therefore, teachers have an important role in the implementation of learning management.

The tahfidz Al-Qur'an program has been included in formal educational institutions, both private and public. Therefore, now there are many integrated Islamic educational institutions that have a superior program of tahfidz Al-Qur'an with the dynamics of each educational institution in developing a tahfidz Al-Qur'an education program in their environment. The development of the tahfidz program in formal education has different challenges compared to other tahfidz Islamic boarding schools. Different challenges lead to differences in the formulation of the objectives of the tahfidz program, the background of tahfidz development, the ability of existing resources, and the availability of other supporting facilities.

In North Sumatra, there have been many integrated Islamic educational institutions that organize training programs for tahfidz Al-Qur'an. Integrated Islamic School is one of the educational institutions that implements the Qur'an as a concept of Islamic education. Muhab et al. (2010:35-36) explained that the Integrated Islamic School comes with a new format in the management of Islamic education while still referring to national education standards. SIT is 
essentially a school that implements the concept of Islamic education based on the Qur'an and As-Sunnah. In its implementation, SIT combines the involvement and active participation of the learning environment, namely school, home and community.

Muhab et al. (2010:372-374) states that the Islamic Religious Education Standards, especially the learning of the Qur'an at SIT are aimed at, 1) fostering a love for the Qur'an; 2) cleanse the mind and feelings and purify the hearts and souls of students; 3) provide the foundation and basics that the knowledge learned comes from the Qur'an. In addition to the objectives, learning the Qur'an at SIT serves as a wasilah for, 1) instilling a sense of calm, comfort and specialness'; 2) habituation to live with the Qur'an; 3) train spiritual, emotional and intellectual intelligence. Then the scope of learning the Qur'an includes recitations, tahsin, tahfidz, tarjim and interpretation.

From the explanation above, the researcher is interested in analyzing and focusing his study on the management of tahfidz Al-Qur'an learning. The researcher saw the uniqueness of the PKBM Homeschooling Abi and Ummi at the Baiti Jannati Islamic Education Foundation Junior High School level in managing their tahfidz learning management. In formal procedures, this school has applied the management of tahfidz Al-Qur'an learning in the continuity of teaching and learning activities. What's interesting about this school is the tahfidz learning plan that is implemented based on Homeschooling. Where teachers get many benefits by making Homeschooling-based learning tools so that teachers can adjust their study time with the subject matter.

\section{RESEARCH METHODS}

This research uses a case study approach. The researcher uses a holistic single-case study method where a case is placed as the focus of the research. This study describes objectively and as is about the management of learning tahfidz Al-Qur'an. The focus of this research is the management of tahfidz learning at public learning center of Homeschooling Abi and Ummi at the Baiti Jannati Islamic Education Foundation Junior High School which includes planning, organizing, implementing and evaluating.

\section{RESULTS AND DISCUSSION}

\section{Planning for Tahfidz Al-Qur'an Learning}

This school is classified into the homeschooling community category. As mentioned by Muhtadi (2012) that the homeschool community is a combination of several multiple homeschooling models with a more structured curriculum as formal education. There is a syllabus, teaching materials, main activities, infrastructure, and learning schedules. The homeschooling base makes this school have high flexibility where the educational vision, methods, learning styles, subject matter to be deepened, study time and others are determined by the foundation itself. This school refers to the official curriculum but prioritizes tahfidz learning as its main program. Based on homeschooling, this school is expected to be able to create a comfortable and fun learning and tahfidz atmosphere so that it can give birth to Hafizh AlQur'an with tahsin quality and able to practice the values of the Qur'an contained in it.

Reading the Qur'an must be in accordance with the rules of recitation, so as not to be mistaken when reading it and not to violate the meaning that results in sin for the reader. Therefore, in studying the Qur'an, it must be with someone who has knowledge in this field, in 
this case the qira'at experts or people who already have the qira'at sanad so that the reading of the Qur'an is in accordance with the reading of the Prophet. As mentioned by Redha bin Mohamad, et al (2020) what is meant by the talaqqi sanad of the Qur'an is the narrator who narrates the reading of the Qur'an continuously from the main source, namely the Prophet SAW, which is obtained face-to-face in front of the teacher. Said and Adam (2011) stated that the reading or qira'at of the Qur'an must be done as the recitations taught by Jibril A.S to the Prophet Muhammad. The readings are delivered in their original form without changes from generation to generation face-to-face and the delivery of the readings is ratified through an accreditation system known as a sanad. This sanad is evidenced by the existence of a document known as a list of teachers or muqri who have taught and certified their qualifications in the accuracy of reading the Qur'an. Usually the title will state qira'at, narration and reading history.

The importance of the teacher's role in the learning process is the basis for the formation of special criteria in the recruitment process. The criteria for determining the tahfidz supervising teacher at this foundation are the quality of tahsin and experience in memorizing the Qur'an, this is in line with the established tahfidz learning objectives. Mujib (2006) If the Qur'an is used as the basis of education, then a teacher must have a character that is in accordance with what is taught in the Qur'an. The teacher acts as a teacher who directs students to the level of maturity and character in accordance with the purpose of God who created them. Mas (2008) states that the teacher is the number one person and has full authority in determining the learning process in the classroom. For this reason, the teacher is said to be the key to success in improving the quality of learning in the classroom. Zein (2016) The role of the teacher in the development of learning is very important because learning is a stage that is very dependent on the competence of a teacher. Ahadi (2017) the teacher is the dominant element in learning, where learning will not be of quality without the role of the teacher, so the abilities that must be possessed and developed by teachers are not limited to conveying material but developing four competencies, namely personality, social, pedagogic and professional competencies.

\section{Organizing Tahfidz Al-Qur'an Learning}

In organizing learning a teacher must be able to choose the right tactical tools, be able to choose the right learning aids, be able to choose the size of the class, and be able to choose the right strategy to communicate complex rules, procedures and teaching. Komalasari (2019) teachers must have tools that support the learning process to take place to assist teachers in delivering material to make it easier, more concise, and the purposes and objectives of the material conveyed. To improve the quality of teachers in guiding the tahfidz of students whose orientation is tahsin in memorizing the Qur'an, the foundation facilitates learning of Al-Qur'an tahsin for supervising teachers three times a week. As mentioned by Rulitawati, et al (2020) that teachers have a central and strategic role in every effort to improve the quality of education. In particular, it leads to improving the quality of educators. Duties and Responsibilities of a teacher are required to have certain abilities and skills, these abilities are part of the teacher's competence.

The learning organization that is applied uses STIFin as a tool to identify students' intelligence machines based on the dominant brain operating system so that they can be used as tactics and learning aids to assist teachers in conveying important learning points. Alindra (2018) the STIFIn concept compiles from theories of psychology, neuroscience, and human resource science. How to find out this intelligence machine with STIFIn Fingerprint, a test carried out by 
scanning the ten fingertips to get fingerprints with a fingerprint tool. Fingerprints that carry information about the composition of the nervous system are then analyzed and linked to certain hemispheres of the brain that dominantly act as operating systems and at the same time become a person's intelligence machine, which is named STIFIn which stands for sensing (abbreviated S), thinking (abbreviated T), intuition (abbreviated I), feeling (abbreviated F), instinct (abbreviated In). By using the literature review method to analyze that the existence of this intelligence machine and genetic personality encourages the development of a more effective human intelligence potential. This is done so that teachers recognize and understand the personality of students so that the delivery of the meaning contained in each material can be conveyed according to the character of students and students are easy to understand and accept.

STIFin is also used by teachers to direct students to identify appropriate memorization methods and is used to take a personal approach to students so that students feel comfortable while memorizing the Qur'an so that a love for the Qur'an grows. Mundiri and Zahra (2017) implemented the STIFIn method in memorizing the Qur'an, making students able to memorize well and comfortably and be able to complete the memorization quickly but difficult to forget. Hidayat (2020) As a concept, STIFIn becomes a systematic and solution program to find a way out of various difficulties, the STIFIn scheme can easily solve any problem that is considered complicated by someone like memorizing the Qur'an.

\section{Implementation of Tahfidz Al-Qur'an Learning}

In practice, the classroom management pattern used by the teacher includes face-to-face small groups so that the learning process is conducive and the teacher can monitor students. Maheasy (2018) class management is an activity or effort to overcome a problem, which aims to create and maintain a classroom atmosphere that supports effective learning programs. The pattern of classroom management in this school is the division of groups in which one supervising teacher is responsible for 8-10 students. Erman (2008) learning activities in groups is a cooperative learning model where students work together and help each other solve problems.

The pattern of implementing tahfidz Al-Qur'an learning is prepared by the tahfidz coach. Scheduling is a form of school effort in increasing the effectiveness of learning. As mentioned by Pratami, et al (2020) Scheduling is needed to make it easier for educators to carry out learning activities at school. Not only that, a preparation of this lesson schedule also plays an important role in achieving the implementation of learning that can be an intermediary for schools in achieving an educational goal.

In the process of implementing learning sometimes find students who experience a condition of decreased morale. In this position, the supervising teacher acts as a motivator and provides solutions to restore students' enthusiasm for learning. Idzhar (2016) states that teachers are the spearhead in improving the quality of education, especially when motivating students. The teacher's role is to become a power motive that encourages someone to do something, teachers need to foster students' learning motivation to obtain optimal learning outcomes in order to achieve a certain goal.

Learning activities do not use special methods or techniques, but if students are found to be inadequate in their tahsin reading, the supervising teacher will mentally aqqikan the verses of the Qur'an which students will memorize to make it easier for students to memorize. In addition to memorizing the Qur'an, students also get material for habituation of Islamic etiquette and the morals of memorizing the Qur'an. In addition, every week there will be a schedule of tahsin and 
practice recitation for students who are directly guided by the tahfidz coach. Through this, it is hoped that it can lead to students' love for the Qur'an and students are able to practice the moral values of each memorized verse. As mentioned by Hidayah (2016) activating and strengthening the role of tahfidz instructors in guiding and motivating students through increasing the volume and intensity of direct involvement of tahfidz teachers in guiding students to memorize istiqamah has a strong effect on students. The intensity of interaction between tahfidz teachers and students is needed so that close communication is established between the two, so that students feel cared for and motivated.

\section{Evaluation of 'Tahfidz Al-Qur'an Learning}

Evaluation in the tahfidz learning process, the teacher continues to monitor the effectiveness of the learning process by balancing the achievement of predetermined targets with students' memorization conditions. According to Magdalena, et al (2020) Evaluation is a process to collect, analyze and interpret information to determine the level of achievement of learning objectives by students.

At the PKBM Homeschooling Abi and Ummi at the Baiti Jannati Islamic Education Foundation Middle School Level, there are several forms of evaluation carried out as a form of benchmark for the effectiveness and efficiency of ongoing learning management, including daily evaluations, monthly evaluations and semester evaluations. Suardipa and Primayana (2020) state that the progress of an activity will look dull without being accompanied by qualified and measurable evaluation content. Systematic and continuous evaluation is needed as a measure of the success of achieving goals and the effectiveness of the learning process. Shofwan et al (2019) stated that learning evaluation is a systematic, continuous and comprehensive process or activity in the context of controlling, guaranteeing and determining the quality (value and meaning) of learning on various learning components. Based on certain considerations and criteria, as a form of educational responsibility in carrying out learning. At each evaluation stage, if the condition of the student's memorization is not adequate, namely the student has not been able to repeat the whole memorization, then a repetition of the stages is carried out in the form of re-depositing the memorization to the supervising teacher and will be retested by the tahfidz coach. This is done to help students achieve learning objectives optimally. From the description above, it can be seen that the object of learning evaluation is not only students, but also involves the teacher. Noer and Rusydiyah (2019) evaluation is able to identify if there are obstacles, as well as use the results of the evaluation as an instrument and measure to improve them. If you have fixed the existing obstacles and obstacles, then the purpose of learning tahfidz Al-Qur'an can be realized. Widoyoko (2009) states that the main object of evaluation of learning programs must include two things, namely, managerial aspects which are the implementation of learning designs that have been prepared by teachers in the form of a learning process or also called evaluation of the quality of the learning process as well as substantial aspects which are student learning outcomes. after following a series of learning processes designed by the teacher, or also called the assessment of student learning outcomes, both using tests and non-tests. 


\section{CONCLUSION}

This study aims to find out more about the management of tahfidz Al-Qur'an learning in PKBM Homeschooling Abi and Ummi at the Junior High School level of Baiti Jannati Islamic Education Foundation. The results showed that:

This school is classified into the homeschooling community category so that it has high flexibility where the educational vision, methods, learning styles, subject matter to be deepened, study time and others are determined by the foundation itself. This school refers to the official curriculum but prioritizes tahfidz learning as its main program in the hope of producing Hafizh Al-Qur'an with tahsin quality and being able to practice the values of the Qur'an contained in it. This is supported by the results of observations that researchers found in the field where in realizing the quality of tahsin bersanad, the foundation collaborates with Ustadz H. Muhammad Ansari, Lc, MTH Al-Hafizh holder of the 30th Al-Qur'an sanad from Shaykh Dr. Proficient Munajjid Ad-Dimasyqi to foster the implemented tahfidz program. To optimize the implementation of tahfidz learning, the foundation developed several plans in the form of recruitment criteria for supervising teachers, standards for new student admissions, preparation of learning programs, and setting memorization targets as a reference for taking action so that learning objectives can be achieved effectively and efficiently.

Organizing learning that is applied using STIFin as a tactical tool and learning aid to help teachers identify students' intelligence machines, this is expected to help teachers recognize and understand students' personalities so that the delivery of the meaning contained in each material can be delivered according to the character of students and students easily to understand and accept. In addition, STIFin is also used by teachers to direct students to identify appropriate memorization methods and is used to take a personal approach to students so that students feel comfortable while memorizing the Qur'an and grow a love for the Qur'an.

The classroom management pattern used by the teacher includes face-to-face small groups in the form of group divisions where one supervising teacher is responsible for 8-10 students. The pattern of implementing the tahfidz Al-Qur'an learning is prepared by the tahfidz coaches, school principals and supervising teachers. There are 6 hours in a day special time provided for tahfizh learning which is divided into 3 meetings, the first 1 hour to increase memorization, the second 3 hours to repeat memorization and the third 2 hours to increase memorization. Learning activities do not use special methods or techniques, but if students are found to be inadequate in their tahsin reading, the supervising teacher will mentally aqqikan the verses of the Qur'an which students will memorize to make it easier for students to memorize. In addition to memorizing the Qur'an, students also get material for habituation of Islamic etiquette and the morals of memorizing the Qur'an. In addition, every week there will be a schedule of tahsin and practice recitation for students who are directly guided by the tahfidz coach.

There are several forms of evaluation carried out as a form of benchmark for the effectiveness and efficiency of ongoing learning management, including daily evaluations, monthly evaluations and semester evaluations. The daily evaluation carried out by the teacher is in the form of student memorization achievements per day. Monthly evaluation in the form of awarding night. The evaluation is in the form of a continuous verse test with the assessment criteria, namely tahsin, recitation, fluency of memorization and the amount of memorization which is directly assessed by the tahfidz coach. The evaluation per semester is in the form of report cards for student memorization achievements for one semester. Systematic and 
continuous evaluation is needed as a measure of the success of achieving goals and the effectiveness of the learning process. At each evaluation stage, if the condition of the student's memorization is not adequate, namely the student has not been able to repeat the whole memorization, then a repetition of the stages is carried out in the form of re-depositing the memorization to the supervising teacher and will be retested by the tahfidz coach. This is done to help students achieve learning objectives optimally.

\section{REFERENCES}

Abdur Rauf Al-Hafidz, Abdul Aziz. 2006. Kiat Sukses Menjadi Hafiz Qur'an. Jakarta: Robbani Abubakar, A. M., Elrehail, H., Alatailat, M. A., \& Elçi, A. 2019. Knowledge management, decision-making style and organizational performance. Journal of Innovation and Knowledge, 4(2), 104-114. https://doi.org/10.1016/j.jik.2017.07.003.

Ahadi, Muhammad. 2017. Pengembangan Kompetensi Profesionalisme Guru untuk Menyiapkan Pembelajaran yang Bermutu. Digital Repository Universitas Negeri Medan. http://digilib.unimed.ac.id/id/eprint/30846

Al Faruq, Umar. 2014. 10 Jurus Dahsyat Hafal Al-Qur'an. Surakarta: Ziyad Books

Alindra, Afridha Laily. 2018. Kajian Aksiologi Metode STIFIn dalam Pemetaan Mesin Kecerdasan Siswa. Undiksha: Jurnal Filsafat Indonesia. Vol. 1, No. 1. https://ejournal.undiksha.ac.id/index.php/JFI/article/view/13971/8673

Ananda, Rusydi. 2019. Perencanaan Pembelajaran. Medan: Lembaga Peduli Pengembangan Pendidikan Indonesia (LPPPI)

Arham bin Ahmad Yasin. 2014. Agar Sehafal Al-Fatihah. Bogor: Hilal Media Group

Buchari, Agustini. 2018. Peran Guru dalam Pengelolaan Pembelajaran. Jurnal Ilmiah Iqra': 2541 2108. http://journal.iain-manado.ac.id/index.php/JII

Buchberger, F., B. Campos, D. Kallos, and J. Stephenson. 2000. Green Paper on Teacher Education in Europe. Umea: Thematic Network of Teacher Education in Europe

Creswell, John W. 2007. Qualitative Inquiry \& Research Design Choosing Among Five Approaches. California: SAGE Publication

Creswell, John W. Alih Bahasa: Ahmad Lintang Lazuardi. 2015. Penelitian Kualitatif dan Desain Riset. Yogyakarta: Pustaka Pelajar

Erman. 2008. Model Belajar dan Pembelajaran Berorientasi Kompetensi Siswa. Educare: Jurnal

$\begin{array}{lllll}\text { Pendidikan dan } & \text { Budaya. }\end{array}$ http://jurnal.fkip.unla.ac.id/index.php/educare/article/view/62/62

Erwinsyah, Alfian. 2017. Manajemen Pembelajaran Dalam Kaitannya Dengan Peningkatan Kualitas Guru. TADBIR: Jurnal Manajemen Pendidikan Islam, Volume 5, Nomor 1, 228816497

Gemnafle, M. \& Batlolona, J. R. 2021. Manajemen pembelajaran. JPPGI: Jurnal Pendidikan Profesi Guru Indonesia, 1(1), 28-42

Halik, Abdul. 2019. Manajemen Pembelajaran Berbasis Islam. Makassar: Global Research and Consulting Institute (Global-RCI)

Herry, Bahirul Amali. 2012. Agar Orang Sibuk Bisa Menghafal Al-Qur'an. Yogyakarta: ProYou Hidayat, Fiqri. 2020. Penerapan Metode STIFIn dalam Menghafal Al-Qur'an di Pondok Pesantren Nurul Jadid Paiton. Academia: Accelerating the world's research. https://www.academia.edu/download/64194402/11140340000198_FIQRI\%20HIDAYA T.pdf 
Raudhah Saragih, Mesiono. Inom Nasution

Hidayat, Rahmat dan Candra Wijaya. 2017. Ayat-Ayat Al-Qur'an Tentang Manajemen Pendidikan Islam. Medan: LPPPI

Hidayah, Nurul. 2016. Strategi Pembelajaran Tahfidz Al-Qur'an di Lembaga Pendidikan. Ta'allum: Jurnal Pendidikan Islam, Vol 04, No. 01. https://doi.org/10.21274/taalum.2016.4.1.63-81

Julaizah, Rabiah, "Manajemen Pembelajaran Tahfidz Al Qur'an Pada SMP Tahfidzul Qur'an AnNajah Cindai Alus Martapura, Pondok Pesantren Darul Hijrah Putra Cindai Alus Martapura Dan Smpit Ukhuwah Banjarmasin", (http://idr.uin-antasari.ac.id/id/eprint/1590, diakses pada tanggal 26 Agustus 2015 pukul 22:19)

Karzun, Anas Ahmad. 2004. 15 Kiat Menghafal Al-Qur'an, (Penerjemah Tiar Anwar Baktiar). Jakarta: Mizan Publika

Komalasari, Eti. 2019. Peran Guru dalam Media dan Sumber Belajar di Era Disrupsi. Prosiding Seminar Nasional Pendidikan FKIP. Vol. 2, No. 1. https://jurnal.untirta.ac.id/index.php/psnp/article/view/5795/4148

Lin Goodwin \& amp; Clare Kosnik (2013) Quality teacher educators = quality teachers? Conceptualizing essential domains of knowledge for those who teach teachers, Teacher Development: An international journal of teachers\&\#39; professional development, 17:3, 334-346, DOI: 10.1080/13664530.2013.813766

Lexi J. Moleong. 2017. Metodologi Penelitian Kualitatif. Bandung: PT. Remaja Rosdakarya

Magdalena, Ina dkk. 2020. Pentingnya Evaluasi dalam Pembelajaran dan Akibat Memanipulasinya. Bintang: Jurnal Pendidikan dan Sains. Vol. 2, No. 2. https://ejournal.stitpn.ac.id/index.php/bintang

Mahmudah. 2018. Pengelolaan Kelas: Upaya Mengukur Keberhasilan Proses Pembelajaran. Jurnal Kependidikan. http://jurnalkependidikan.iainpurwokerto.ac.id

Mahyudi, Tuti. 2013. Pelaksanaan Strategi Pembelajaran Pendidikan Seni Budaya Sub Bidang Studi Seni Rupa SMA Negeri I Kinali Pasaman Barat. The Journal of Art Education: Vol 1, No 3. http://ejournal.unp.ac.id/index.php/serupa/article/view/1905

Mas, Siti Roskina. 2008. Profesionalitas Guru dalam Peningkatan Kualitas Pembelajaran. Jurnal Inovasi: Vol. 5, No. 2. http:// jurnal.ung.ac.id/index.php/JIN/article/view/797/740

Masrofik. 2019. Tesis: “Pengelolaan Program Tahfidz Al-Qur'an”. Malang: UIN Maulana Malik Ibrahim

Mesiono. 2019. Islam dan Manajemen. Medan: Perdana Publishing

Millah, Uli Rifatul. 2018. Tradisi Pemberian Sanad Al-Qur'an (Studi Pada Pondok Pesantren Tahfidzul Qur'an Baitul Abidin Darussalam Wonosobo Jawa Tengah dan Pondok Pesantren Miftahul Huda Al-Azhar Banjar Jawa Barat. Institut Ilmu Al Quran (IIQ) Jakarta http:/ / repository.iiq.ac.id// handle/123456789/752

Muhab, dkk. 2010. Standar Mutu Sekolah Islam Terpadu. Jakarta: JSIT Indonesia: Empowering Islamic Schools

Muhlasin. 2019. Manajemen Pembelajaran dalam Rangka Meningkatkan Prestasi Belajar. Akademika: Vol. 15 No. 1 Juni. https://media.neliti.com/media/publications/332416manajemen-pembelajaran-dalam-rangka-meni-9094e8b5.pdf

Muhtadi, Ali. 2012. Pendidikan dan Pembelajaran di Sekolah Rumah (Homeschooling). Jakarta: Raja http:/ /staffnew.uny.ac.id/upload/132280878/penelitian/11.+Pendidikan+dan+ pembelajar an + di + sekolah + rumah $+($ home + schooling)-tinjauan + teoritis + dan + praktis.pdf 
Mujib. Abdul. 2006. Ilmu Pendidikan Islam. Jakarta: Kencana Prenada Media.

Munandar, Jono M., dkk. 2014. Pengantar Manajemen. Bogor: IPB Press

Mundiri, Akmal dan Irma Zahra. 2017. Implementasi Metode STIFIn dalam Meningkatkan Kemampuan Menghafal Al-Qur'an di Rumah Qur'an STIFIn Paiton Probolinggo. http://dx.doi.org/10.15642/jpai.2017.5.2.201-223

Noer, Syaifudin dan Evi Fatimatur Rusydiyah. 2019. Edureligia: Jurnal Pendidikan Agama Islam. Vol. 3, No. 2. https://core.ac.uk/reader/322565510

Pratami, Risti dkk. 2020. Pengaruh Penyusunan Jadwal Pada Jenjang Pendidikan Dasar Terhadap Efektivitas Pembelajaran Peserta Didik. Seminar Nasional Arah Manajemen Sekolah Pada Masa Dan Pasca Pandemi Covid-19. http://conference.um.ac.id/index.php/apfip/article/download/423/374

Purnamasari, dkk. 2021. Kurikulum Pusat Kegiatan Masyarakat Berbasis Qur'an. Universitas PGRI Semarang. Diklus: Jurnal Pendidikan Luar Sekolah. https://journal.uny.ac.id/index.php/jurnaldiklus/article/view/36532/15454

Redha bin Mohamad, Mohamad dkk. 2020. Relevansi Pewarisan Sanad Talaqqi Al-Qur'an. Jurnal al-Turath; Vol. 5, No. 1. http://spaj.ukm.my/jalturath.

Ridhani, Ahmad Khatib. 2016. Manajemen Pembelajaran di Sekolah. Malang: Prosiding Konferensi Nasional B. Arab II. http://prosiding.arabum.com/index.php/konasbara/article/view/94/87

Rulitawati, dkk. 2020. Model Pengelolaan Kinerja Guru. Palembang: Tunas Gemilang Press. https://books.google.com/books?hl=id\&lr=\&id=GvvqDwAAQBAJ\&oi=fnd\&pg=PR3\& $\mathrm{dq}=$ STIFIn + sebagai + alat + bantu+belajar\&ots $=$ uWDRYtAc38\&sig=ukzHsy1Jof2BXWW2 o7Mz70JDJug

Rusman. 2009. Manajemen Kurikulum. Jakarta: Rajawali Pers

Said, Khairuddin dan Jamaluddin Adam. 2011. Corak Tariq Sanad Pengajian Al-Qur'an di Negeri Pahang. Quranica: International Journal of Quranic Research. Vol. 1, No. 1. http://sare.um.edu.my/index.php/quranica/article/view/5283

Sanjaya, Wina. 2013. Kurikulum Pembelajaran. Jakarta: Kencana

Shofwan, Imam dkk. 2019. Implementasi Pembelajaran Nonformal pada Sekolah Dasar Qur'an Hanifah di Kota Semarang. JPPM: Jurnal Pendidikan dan Pemberdayaan Masyarakat. https://journal.uny.ac.id/index.php/jppm/article/view/23434

Suardipa, Putu dan Kadek Hengki Primayana. 2020. Peran Desain Evaluasi Pembelajaran Untuk Meningkatkan Kualitas Pembelajaran. Widyacarya: Jurnal Pendidikan, Agama \& Budaya. Vol. 4 , No.

http://jurnal.stahnmpukuturan.ac.id/index.php/widyacarya/article/view/796/680

Sugiyono. 2010. Metode Penelitian Pendidikan, Pendekatan Kuantitatif, Kualitatif dan R\&D. Bandung: Alfabeta

Sumardiono. 2007. Homeschooling: A Leap for Better Learning, Lompatan Cara Belajar. Jakarta: PT Elex Media Komputindo

Suryana, Dadan dan Nelti Rizka. 2019. Manajemen Pendidikan Anak Usia Dini Berbasis Akreditasi Lembaga. Jakarta: Prenada Media Group

Susanto, Ahmad. 2018. Konsep, Strategi, dan Implementasi Manajemen Peningkatan Kinerja Guru. Depok: Prenada Media Group

Syafaruddin dan Irwan Nasution. 2016. Manajemen Pembelajaran, Jakarta: Quantum Teaching 
Widoyoko, Eko Putro. 2009. Optimalisasi Peran Guru dalam Evaluasi Program Pembelajaran. Academia: Accelerating the world's research. https://www.academia.edu/download/38603868/Optimalisasi_Peran_Guru_dalam_Evalu asi_Program_Pembelajaran.pdf

Winaryati, Eny. 2014. Evaluasi Supervisi Pembelajaran, Yogyakarta: Graha Ilmu

Yahya bin Syaraf, Imam Abu Zakariya. 2005. At-Tibyan (Adab Penghafal Al-Qur'an), Alih Bahasa, Umniyyati Sayyidatul Hauro', Shafura Mar'atu Zuhda, Yuliana Sahadatilla. Sukoharjo: Maktabah Ibnu Abbas

Yamin, Martinis dan Maisah. 2009. Manajemen Pembelajaran Kelas, Strategi Meningkatkan Mutu Pembelajaran. Jakarta: GP Press

Yin, Robert K. 2002. Case Study Research Design \& Methods. SAGE Publication. Applied Social Research Methods Series Volume 5.

Yin, Robert K. Alih Bahasa: M. Djauzi Mudzakir. 2002. Studi Kasus (Desain dan Metode). Jakarta: Rajawali Pers

Zein, Muh. 2016. Peran Guru dalam Pengembangan Pembelajaran. Jurnal Inspiratif Pendidikan: Vol. 5, No. 2. http://journal.uin-alauddin.ac.id/index.php/InspiratifPendidikan/article/view/3480/3267 